\title{
A study of the determinants of environmental disclosure quality: evidence from French listed companies
}

\author{
Fatma Baalouch ${ }^{1} \cdot$ Salma Damak Ayadi ${ }^{1} \cdot$ Khaled Hussainey $^{2}$ \\ Published online: 3 July 2019 \\ (c) The Author(s) 2019
}

\begin{abstract}
We examine the impact of various factors on the quality of environmental disclosure. Combining multi-theories in a unique framework, it focuses on factors related to the strategy and vision of the firm (environmental audit, presence of an environmental committee), diversity of and within boards (independence of the board, gender diversity) and factors related to the environment (environmental performance, degree of pollution of the company). This study involves an attempt to develop a self-constructed index to measure environmental disclosure quality using qualitative attributes as provided by IASB and GRI frameworks and following (Chauvey et al. in J Bus Ethics, 130(4):789-803, 2014). A number of econometric techniques are used including panel data specifications using a sample of French listed companies in SBF120 for the period 2009-2014. The study found that quality of disclosure remains relatively low. In addition, the findings indicate that a company's strategy and vision (environmental audit), diversity in boards (gender diversity) and environmental performance play significant roles in explaining variations in quality of environmental disclosure. This paper sheds light on whether various factors could affect the credibility of disclosed information using a multi theory framework. Standards setters and policy makers are recommended to think about implementing a generally accepted framework of non-financial reporting to answer the demand for more transparency and accountability. This paper fills the gap in the literature by highlighting an unexplored area of literature related to the quality of non-financial reporting drawing upon the regulatory framework of financial reporting.
\end{abstract}

Keywords Environmental disclosure $\cdot$ Disclosure quality $\cdot$ Strategy and vision · Diversity $\cdot$ Environmental performance $\cdot$ France

Khaled Hussainey

khaled.hussainey@port.ac.uk

Extended author information available on the last page of the article 


\section{Introduction}

Over the last few years, researchers have attempted to study the motivations behind disclosing non-financial information in different contexts. However, there is a sense that what has been concluded so far is partial, contradictory and inconclusive leading to the need for different methods of research (Spence and Gray 2007). This paper proposes to study the effect of various factors on the quality of environmental disclosure, which has attracted major interest in recent scholarly literature. The motivations for the current study arise from the nature of the regulatory framework of environmental disclosure in the French context and from the gaps in the literature. Our study based on the French context, which characterized by a widely implemented regulatory framework of environmental disclosure. France considered as pioneer country that has enacted legislation for mandatory social and environmental disclosure. At first, the NRE Act (Nouvelle Regulation Economique) was launched in 2001, which requires listed companies to integrate social and environmental information into their annual reports. However, much criticism has been directed toward this law for the lack of its specificity (Chauvey et al. 2014). They indicate that existing French regulation does not appear to improve the quality of CSR disclosure and still seems to be more about legitimization than transparency. Consequently, the Grenelle Act II of 2012 was set up to address the gaps in the first law. This act calls for more credibility and transparency of disclosed information as it requires third-party verification.

Moreover, this study is set up to fill the gap in prior literature and seeks to respond to the call of many scholars to search for a comprehensive and sensible measure of disclosure quality. For example, Beattie et al. (2004: 233) argue that: "Researchers investigating the determinants of disclosure quality could be wasting their effort if the primary variable of interest is not being measured with a sufficient degree of accuracy". In addition, environmental reporting quality has not been universally acclaimed given its challenge in providing accurate and transparent information (Kolk 2008). In addition, non-financial disclosure has been always criticized for a lack of relevance and credibility (Michelon et al. 2015). Furthermore, prior research fails to provide an accurate measure of environmental disclosure quality due to the lack of convincing theoretical underpinning and the subjectivity that surround the developed proxies.

Thus, to fill this gap, we focus on the quality of environmental disclosure and factors that may influence such reporting. We confute the assumption that a high volume of disclosed environmental information contributes to a high quality of disclosure, following Brammer and Pavelin (2008) who find that prior studies on environmental disclosure suffer from difficulties in measuring quality. We also confute the statement of Botosan (2004) that the disclosure quality is inherently immeasurable. Moreover, Beattie et al. (2004) note that, given the weaknesses and limitations of previous approaches to measuring disclosure, it is essential to provide new ways and provide proxies for disclosure quality, which will develop a comprehensive disclosure profile. Beretta and Bozzolan (2008) indicate that quantity is not a good proxy for disclosure quality in assessing 
narrative disclosure and the richness and quantity of disclosure are two independent dimensions. Due to the absence of norms and standards related to non-financial reporting and, in support of our preposition, we follow (Solomon 2000) and the Federation des Experts Comptables Européeanne (FEE 1999) who argued that environmental disclosure, which could shadow financial reporting and qualitative principles and frameworks, as applied successfully to financial reporting, can be effectively applied to environmental disclosure'.

Very few studies have investigated the possibility of using the qualitative attributes of financial reporting to construct a measure for corporate environmental reporting. Our research seeks to shine new light on these debates through an examination of the environmental disclosure quality under the conceptual framework of financial reporting. We follow Chauvey et al. (2014) to construct our disclosure quality index using attributes as discussed by the International Accounting Standards Board, the Financial Accounting Standards Board, and the Global Reporting Initiative.

Relying on a multiple theory framework: stakeholders theory, neo institutional theory, resource dependence theory and human capital theory, for the study's basic sample group, we selected French publicly listed companies in the SBF 120 index for the period 2009-2014. This based on multi-theoretical framework because environmental reporting is a complex phenomenon that cannot be explained by a single theory (Tagesson et al. 2009). In this study, we use both univariate and multivariate regression models to examine how a company's strategy and vision which are manifested by the environmental audit and existence of an environmental committee. In addition, this study, then, is intended to fill a gap by distinguishing diversity among boards from diversity within boards and their effects on environmental disclosure (Hafsi and Turgut 2013). Finally, we study the influence of firm's environmental performance and degree of pollution on environmental disclosure quality.

Findings are generally consistent with our expectations. First, consistent with neo institutional theory firms that adopt environmental audit is likely to provide higher quality environmental information. Second, board diversity manifested by gender diversity has an observable impact. In addition, environmental performance is positively and significantly associated with both dimensions. To the best of our knowledge, this is the first such study undertaken in France that sheds new light on the quality of environmental disclosure and their relationships with various factors.

The remainder of the paper is organized as follows. The next section presents a survey of theoretical and empirical literature in order to develop our hypothesis. The Sect. 3 illustrates the research methodology in term of sample, data and models. The Sect. 4 is dedicated to empirical findings. The final section offers a discussion of our findings and makes concluding comments.

\section{Background and hypothesis development}

This section aims to explore prior research related to the determinants of environmental disclosure quality in order to develop our hypothesis. We first cover the multi- theory framework and then the factors that might affect disclosure quality. 


\subsection{Environmental disclosure quality}

There is no universal accepted definition of environmental disclosure quality. However, authors such as Brammer and Pavelin (2008) state that its quality relates to its value relevance to a variety of interested and outside parties and is subject to external audit. It is determined by the usefulness of environmental information to users for better decision-making (Ane 2012). On the other hand, De Villiers and Van Staden (2011) wrote on the audit of this information in order to ensure its reliability and to hold managers accountable for the environmental impact of their decisions. Michelon et al. (2015) define the richness of CSR information as the extent to which information helps users appreciate the social and environmental impact of corporate activities and to infer management's approach to CSR. Each of the aforementioned definitions refers to a particular characteristic of information and is dependent upon the purpose of the research.

\subsection{Theories regarding environmental disclosure}

Given the lack of a common theoretical framework, prior literature typically emphasizes the determinants of non-financial reporting using socio-political and economic based theories (Braam et al. 2016). At this level, Gray and Handley (2015) argue that CSR is a multidimensional complex activity which cannot be explained by a single theoretical perspective because it depends on complementary forces. NeoInstitutional theory has been widely used in prior studies related to social and environmental disclosure based on the assumption that organizations tend to use such disclosure to respond to various pressures from the institutional environment. DiMaggio and Powell (1983) noted that the key aspect of institutional theory as isomorphism. ${ }^{1}$ The aim of this theory is to explain the behavior of organizations with reference to their institutional environment when companies have to comply. In the context of current research, Monjarret (2014) notes that verification of social and environmental information in the French context is considered to be a response to normative pressures exercised by the Grenelle Act II which constitutes the process from which public authorities attempt to regulate CSR practices. Stakeholder theory is another frequently adopted theoretical perspective, which sheds light on the intensity of conflicting powerful stakeholder' demands and preferences. Stakeholder theory indicates that organizations focus on broad concepts of overall accountability to various stakeholders. It will probably provide a clear explanation for the willingness of companies to provide high quality environmental information (Liao et al. 2014). Another recognized theory is the resource dependence theory, which recognizes the influence of external factors on the organizational behavior of the firm (Hillman and Dalziel 2003). At this level, managers will search to avoid dependence on their external environment and reduce uncertainty by focusing on the resources of the firm. At this level, Pfeffer and Salancik (1978) focus on the need to match

\footnotetext{
1 Which refer to the similarity in forms and processes and the homogeneity in structures and practices by organisations in order to conform to predominant norms and traditions (DiMaggio and Powell 1983).
} 
the needs of the company with the resources provided by the board since the board of directors is considered as a sum of capital (human and social capital) which will affect both monitoring and resource provision (Hillman and Dalziel 2003). According to Bear et al. (2010), RDT is used as the theoretical underpinning of the impact of gender diversity in the board on CSR and CSR reporting, since it relies on the key functions of the board. Human capital theory is considered a complement to the resource dependence theory, as it discusses how education, experience and skills of human capital can benefit the organizations (Carter et al. 2010). The origin of the human capital theory dates back to the work of Becker (1964) that addresses the role of a person's stock of education, experience and their marketable skills in improving a firm's performance. In our case, the human capital theory is needed to discuss the diversity performance relationship (Terjesen et al. 2009).

\section{Hypothesis development}

Empirical research on the determinants of environmental disclosure is exhaustive and provides partial, contradictory and inconclusive results (Spence and Gray 2007). Whereas, factors influencing the quality of environmental disclosure still not discussed.

\subsection{Factors related to the strategy and vision of the firm}

These are factors related to the strategy and vision of the firm in terms of environmental issues. They include the existence of an environmental or CSR committee on the board and environmental audit.

\subsubsection{Presence of environmental committee}

The establishment of an environmental committee is viewed as a capital resource for the firm. The experience, skills and knowledge of such a committee are expected to play a crucial role in ensuring a better quality of environmental reporting (Amran et al. 2013). This supports the expectation that an environmental committee within the board of directors will monitor and promote management activities while seeking ways to increase the firm's alignment with stakeholders' interests (Peters and Romi 2012). Prior research on CSR reporting has shown that the existence of an environmental committee within the board shows a company's commitment towards sustainability and its willingness to manage the conflicts between different stakeholder groups. As indicated by Peters and Romi (2012), the presence of an environmental committee helps companies to evaluate reporting systems and affects their quality. The EC has been seen as a signal of board orientation toward environmental accountability, which includes adequate communication with external stakeholders (Liao et al. 2014). In the same vein, Michael and Jill (2009) indicates that firms establish EC's in order to address environmental issues from the perspective of risks and strategic opportunities of 
their powerful stakeholders. To sum up, we consider that the presence of an environmental committee within the board may be seen as a monitoring device for improving environmental disclosure and demonstrating accountability towards powerful stakeholders. Therefore, we propose the first hypothesis:

H1 Firms with an environmental committee provide high quality environmental disclosure.

\subsubsection{The environmental audit}

Environmental audit is implemented in France in order to monitor compliance with new laws and regulations related to non-financial disclosure. We draw on the neo-institutional perspective to build this hypothesis. In the French context external assurance of environmental information considered as normative pressure. Listed companies have to comply with the requirement of the article 225 of the Grenelle Act II, which requires a third party verification of disclosed information in order to ensure credibility. It is a response to public pressure about the insufficient reliability and the lack of accuracy of environmental information (Braam et al. 2016). In the same vein, GRI (2013) highlights the importance of sustainability reporting's assurance and its role in increasing recognition, trust and credibility for stakeholders. However, owing to the relative newness of the practice, empirical analysis of CSR assurance is limited and few studies to date investigate its impact (Brikey et al. 2016). Proactively signaling the credibility of their corporate environmental reporting practice, environmental audit influences the perceptions of a company regarding its accountability, thus increasing stakeholder's trust and corporate reputation (Braam et al. 2016). Therefore, from neo institutional perspectives and given the debate over the use of assurance practices, we extend prior research by examining the role of environmental assurance in enhancing the quality of environmental disclosures. We consider environmental audit as a response to normative pressure exercised by French regulation to improve transparency and credibility of environmental information. Thus, we formally state the second hypothesis:

H2 External assurance of environmental information is positively associated with the quality of environmental disclosure.

\subsection{Diversity in/of the board}

We focus on the impact of boardroom diversity through gender diversity and independence of the board. The choice of these characteristics is due to their impact on the strength of corporate governance. It is assumed that the strength of the board of directors is closely related to the degree of independence and diversity of its members (Prado-Lorenzo and Garcia Sanchez 2010). 


\subsubsection{Gender diversity}

Our expectations of the impact of gender diversity on environmental reporting quality is supported by empirical research and multi theoretical framework. Resource dependence theory and human capital theory indicates that firms tend to match between their needs and the resources provided by board members, such as education, experience and skills to benefit the organization and take into account ethical considerations such as environmental commitments. In this sense, the role of women on the board as well as on top-level positions has become a hot topic of research in accounting, management, etc. Literature suggests that companies with a greater number of females on their boards are an important dimension of corporate governance, because culturally, traditionally and socially, women are different from men (Liao et al. 2014). Forte (2004) provides evidence that women are more likely than men to identify situations requiring ethical judgment and to behave ethically. Some have argued that women may be more aware of environmental issues and are more concerned about reducing perceived risks (Post et al. 2011). In France, the context of our study, the law requires 50\% gender parity on the board of every public firm by 2015 (Post et al. 2015). Adams et al. (2015) indicates that men and women present differences in terms of ethical behavior and those female directors have different values and are more stakeholders oriented. From a cultural point of view, women are considered to care more about the quality of life than material success (Hofstede et al. 2010) which leads them to be more concerned about the environmental commitment of the company and the wellbeing of the society.

Our expectation that the presence of females on boards of directors affects environmental disclosure is further supported by empirical research. Adams and Ferreira (2009) observe female directors to have a similar impact to that of independent directors. They may demand greater environmental reporting quality. In addition, firms with a high percentage of women on the board of directors are more socially responsible (Seto-Pamies 2013). Recent research suggests that board gender diversity may affect reporting quality, compliance and ethical behavior. Al Shaer and Zaman (2016) find a positive influence of female presence in the board on sustainability reporting quality. Bear et al. (2010) provide evidence that females on the boards positively influence the strength rating for CSR. Moreover, Ben Amar et al. (2015) note that female representation on the board enhances board effectiveness in stakeholders' management and promotes the adoption of sustainability initiatives related to reporting about climate change.

To sum up, while the importance of board gender diversity is widely recognized, empirical evidence on its benefits and impact on environmental reporting, even though limited, are inconclusive and have produced mixed results (Harjoto et al. 2015). From the extensive literature review, it is predicted that female representation on boards of directors may affects environmental reporting. The hypothesis is stated as follows:

H3 Gender diverse boards have a positive association with the quality of environmental disclosure. 


\subsubsection{Board independence}

The presence of independent directors on boards is pivotal since they contribute by their experience to the firm Board independence (Barros et al. 2013). They play a crucial role in making decisions related to the ethical commitments of the firm, such as CSR, in order to be accountable towards a wide range of stakeholders (Rao and Tilt 2015). The influence of independent directors on CSR activities has been the subject of few theoretical and empirical studies in the French context (Ducassy and Montandrau 2015). In this regard, several authors affirm that board effectiveness in dealing with non-financial disclosure must be determined by its independence because it is closely related to the strength of the board (Garcia-Sanchez and Martinez Ferrero 2016). Independent directors contribute by their skills, connections and contacts to satisfy all stakeholders, thus ensuring corporate survival (Fuente et al. 2017). On this level, Ibrahim and Angelidis (1995) consider that the presence of outside independent directors reinforces the monitoring role of the board, as they are more sensitive to society's needs and more concerned with ethical matters. Moreover, authors like Zahra and Stanton (1988) report that independent directors are more interested in compliance with laws, regulations, and responsible behavior by the organization. Regarding environmental reporting, Rupley et al. (2012) indicate that the presence of independent directors assists companies in achieving strategic goals and provides perspectives that may affect a firm's willingness to publish transparent environmental information available to a wide range of stakeholders. For all these reasons, prior studies find that independent directors overall broader accountability to stakeholders is linked to the propensity of GHG disclosure (Liao et al. 2014). The previous arguments lead us to state this prediction formally as our fourth hypothesis.

H4 The quality of environmental disclosure is positively related to board independence.

\subsection{Factors related to the environment}

These factors include a firm's environmental performance and degree of pollution caused by the company.

\subsubsection{Environmental performance}

Stakeholder theory suggests that companies should be more accountable to their stakeholders and need to signal their high performance to their most powerful stakeholders. At this level, firms need to pay more attention to the quality of disclosed information. As indicated by Dhaliwal et al. (2014), it is important to control for environmental performance when studying environmental disclosure. Prior research has extensively reviewed this relationship and provides mixed results. Superior environmental performers tend to signal this by disclosing relevant information to 
stakeholders in order to gain a competitive advantage such as improving corporate reputation (Braam et al. 2016). To distinguish themselves from poor performers, good environmental performers employ more objective and verifiable environmental disclosure to ensure credibility and accuracy for stakeholders (Clarkson et al. 2008). In the French context, Chelli et al. (2014) from an institutional perspective provide evidence that firms with poor environmental performance will engage in more extensive offsetting disclosure in an attempt to address increased threats to their legitimacy. On the other hand, Dhaliwal et al. (2014) find that CSR disclosure is used by companies as a positive signal demonstrating confidence in their performance to investors or to offer an explanation in case of poor performance.

To sum up, the association between environmental performance and environmental disclosure has been widely examined and findings remain inconclusive and show conflicting results. This could be due to the use of inappropriate proxies for environmental performance. Therefore, we state the following hypothesis:

H5 Higher quality environmental disclosure is positively associated with a company's environmental performance.

\subsubsection{Degree of pollution of the company}

There is growing scientific evidence of the effects of greenhouse gas (GHG) emissions on global warming (Stern 2006). Consequently, concerns about climate change and global warming have prompted governments to set up policies and regulations in order to reduce industrial carbon emissions. Moreover, the issue of climate change has attracted considerable attention from various institutional investors and other stakeholders (Matsumura et al. 2014). For the context of our research, France is considered a pioneer country in terms of environmental regulation and the fight against climate change. On the other hand, the phenomenon of climate change has received considerable attention from academic research, which focuses mainly on the disclosure by firms of information about their GHG emissions. The majority of these studies focus on the determinants of disclosure on GHG emissions as in (Liao et al. 2014) who consider that information about GHG emissions is vital for the decision making of stakeholders.

For the purpose of our study, we consider GHG emissions as an indication of the degree of pollution of the firm and the disclosure of such information will increase the transparency of the firm and the accountability toward stakeholders. This type of information allows firms to respond to various pressures and to provide complete information about their environmental concerns. Based on NeoInstitutional theory we consider that the publication by the firm of their GHG emissions is a response to coercive pressures exerted by the Grenelle Act II. On this level, we focus in the current study on the degree of pollution of the firm measured by their $\mathrm{CO}_{2}$ emissions. We consider the disclosure of such information as contributing to the completeness of published information. It may be considered as a determinant of quality. We, therefore, hypothesis that: 
Table 1 Variables description

\begin{tabular}{|c|c|}
\hline Definition & Measurement \\
\hline \multicolumn{2}{|l|}{ Dependent variable } \\
\hline ED QUAL & {$\left[\frac{\text { Relevance }+ \text { Neutrality }+ \text { Clarity }+ \text { Comparability }+ \text { Verifiability }}{5}\right]$} \\
\hline \multicolumn{2}{|l|}{ Independent variables } \\
\hline \multicolumn{2}{|c|}{ Variables related to strategy, vision of the company } \\
\hline ENVT COM & $\begin{array}{l}\text { 1: Presence of board environmental committee } \\
0 \text { : Otherwise }\end{array}$ \\
\hline ENVT AUD & $\begin{array}{l}\text { 1: Presence of environmental audit/assurance } \\
0 \text { : Otherwise }\end{array}$ \\
\hline \multicolumn{2}{|l|}{ Diversity in the board } \\
\hline GEND DIV & $\begin{array}{l}\text { Percentage of women in the board members at the end of the fiscal } \\
\text { year }\end{array}$ \\
\hline INDEP & $\begin{array}{l}\text { Percentage of independent board members as reported by the } \\
\text { company }\end{array}$ \\
\hline \multicolumn{2}{|c|}{ Variables related to the environment } \\
\hline ENVT PERF & ASSET4 Environmental score \\
\hline D-POLL & Natural $\log$ of total $\mathrm{CO}_{2}$ and $\mathrm{CO}_{2}$ equivalents emissions \\
\hline \multicolumn{2}{|l|}{ Control variables } \\
\hline STAND REPORT & $\begin{array}{l}\text { Release of a stand-alone report: dummy variable equal to } 1 \text { if } \\
\text { company releases a stand-alone CSR report, } 0 \text { otherwise }\end{array}$ \\
\hline SIZE & The natural $\log$ of total assets \\
\hline PROF & Net income/total assets in $\%$ \\
\hline LEVERAGE & Debt to Assets ratio \\
\hline
\end{tabular}

H6 The degree of pollution of the company is positively related to the quality of environmental disclosure.

\section{Research design}

\subsection{Sample and data collection}

To test the hypothesis developed above, the present research focuses on the French context, essentially firms listed in SBF120, which covers the most 120 actively traded stocks listed in Paris over a six-year period (2009-2014) classified using the ICB industry classification. Using large companies contributes to a better exploration and analysis of the research question. Following El Ghoul et al. (2011), we do not exclude financial companies as they are concerned by the existing regulation. We cover this long period because it provides the opportunity to draw out trends in environmental disclosure over time and to highlight different regulations such as the NRE Act of 2001 and then the Grenelle Act of 2012. The final sample is identified as 570 firm-observations (see Table 1). 
Table 2 Sample composition

\begin{tabular}{lc}
\hline Number of observations excluded & $\begin{array}{l}\text { Reason of } \\
\text { exclusion }\end{array}$ \\
\hline Total observations at start & 720 \\
Missing annual reports & 37 \\
Missing data in ASSET4 & 113 \\
Total number of excluded observations & 149 \\
Final sample & 570
\end{tabular}

Annual and standalone reports are collected from companies' homepages. Other data are extracted from the ASSET 4 database of Thomson Reuters. Data related to financial information are gathered from DataStream.

\subsection{Empirical model}

To test our hypotheses, all continuous variables are winsorised at the 1 st and 99th percentile of observations for the distribution of any of the regression variables. A fixed effects regression was applied. We run a Hausman test which indicates a value 19.93 and Prob $>$ chi $2=0.0299$ for the quality model. Therefore, fixed effects model is the more appropriate for panel data. However, our model suffer from Heteroskedasticity and a first order serial correlation in error terms. Then, in order to address this problem, individual and time fixed effects regression is modeled with the cluster option, which would provide robust estimates of the regression parameters according to Hoechle (2007). On this sense, Petersen (2009) found that in the presence of auto-correlation and heteroscedasticity in the data sets, the standard errors that are clustered by firms are unbiased and produce correctly sized confidence intervals. Moreover, time effects are employed to counter any unobserved cross-sectional and time series dependence. In addition, the analyses include industry dummies to control for the industry effect. The main regression model defined in the following equation:

$$
\begin{aligned}
\text { ENV DISC QUAL }= & \beta 0+\beta 1 \text { ENVT COM }+\beta 2 \text { ENVT AUDIT } \\
& +\beta 3 \text { GEND DIV }+\beta 4 \text { INDEP }+\beta 5 \text { ENVT PERF } \\
& +\beta 6 \text { D }- \text { POLL }+\beta 7 \text { SIZE }+\beta 8 \text { PROF }+\beta 9 \text { LEV } \\
& +\beta 10 \text { STAND REPT }+ \text { Year Fixed Effects } \\
& + \text { Industry Fixed Effects }+\varepsilon_{\mathrm{i}}
\end{aligned}
$$

where $\boldsymbol{\beta}_{\mathbf{0}}$, the regression intercept; $\boldsymbol{\beta}_{\mathbf{1}} \ldots \boldsymbol{\beta}_{\mathbf{1 0}}$, the regression coefficients; $\boldsymbol{\varepsilon}_{\mathbf{i}}$, the error term.

Table 2 summarises the definitions and measurements of the variables. 


\subsection{Variables measurement}

\subsubsection{Environmental disclosure quality}

Manual content analysis is used to measure the quality of environmental information disclosed by companies in annual and standalone reports. "Appendix 1" details the disclosure index for environmental disclosure. In terms of quality, the lack of a comprehensive conceptual framework for non-financial reporting and the absence of standards and norms led us to think about drawing upon the conceptual framework for financial reporting to construct a measure of environmental disclosure quality. We rely on the proposition of Solomon (2000) that environmental reporting could shadow financial reporting and qualitative attributes could be used to measure environmental disclosure quality. In the same vein, FEE provide evidence that qualitative principles as applied successfully to financial reporting can be effectively applied to environmental disclosure. We follow Chauvey et al. (2014) to measure disclosure quality based on the review of GRI guidelines and the conceptual frameworks of both the IASB and the FASB. Several authors, such as Alotaibi and Hussainy (2016), have applied this approach for Saudi Arabian companies and, Michelon et al. (2015) in the UK to measure non-financial disclosure quality. For financial reporting, Beest et al. (2009) used the qualitative characteristics of information to provide a comprehensive measure of information quality.

An un-weighted approach was used to construct an operationalized measure of environmental disclosure quality based on qualitative characteristics of accounting information. This approach is relevant to all users' groups of corporate reports because it helps to avoid the subjectivity of the researcher in coding the items used in the weighted method (Cooke 1989). The study adopts five attributes, which are 'Relevance', 'Neutrality', 'Clarity', 'Comparability' and 'Verifiability' following the index provided by Chauvey et al. (2014) in the French context (see details in "Appendix 2"). We determine an index for each attribute. Then, following, Michelon et al. (2015) we compute a synthesis of the five qualitative characteristics indexes using the simple arithmetic mean as follows:

$$
E D Q U A L_{i t}=\frac{\left[R E L V_{i}+N E U T_{i}+C L A R_{i}+C O M P_{i}+V E R F_{i}\right]}{5}
$$

In using content analysis, it is important to check the validity and reliability of constructed indices (Milne and Adler 1999). The concepts of reliability and validity were carefully considered and assured in this study. Both supervisors revised the disclosure quality index independently before making it final to ensure the validity of the instrument. The comments and feedback received from both supervisors were considered and used to revise the initial checklist of items. Both supervisors revised the disclosure quality index independently before making it final to ensure the validity of the instrument. For the purpose of this study, we apply the inter-coder reliability using one single coder. 


\subsubsection{Variables of interests}

We focus on six main variables of interest. The variable ENV COM is a dummy variable equal to 1 if a company has a board level environmental committee and 0 otherwise (Amran et al. 2013). ENVT AUD is a dummy variable equal to 1 if the firm adopts environmental audit and 0 otherwise (Simnett et al. 2009). GEND DIV is measured by the percentage of female on the board. INDEP is the percentage of independent directors on a firm's board of directors (Kassinis et al. 2016). ENVT PERF measures a firm's environmental performance measured as the environmental score provided by ASSET4 ${ }^{2}$ (Del Bosco and Misani 2016). The variable D-POLL is the degree of pollution of the company measured as the natural logarithm of total $\mathrm{CO}_{2}$ and $\mathrm{CO}_{2}$ equivalents emissions (Matsumura et al. 2014).

\subsubsection{Control variables}

We use a set of control variables based on prior literature. We test the SIZE of the firm measures as the natural logarithm of the firm (Liao et al. 2014). PROF is the profitability of the company using the return on assets (ROA) measured as the net income to the total asset ratio (Braam et al. 2016). LEV is the financial leverage of the firm that equals debt to total assets (Ducassy and Montandrau 2015). Finally, STAND REP is a dummy variable equals 1 if the firm issues a standalone report and 0 otherwise (Michelon et al. 2015). Table 1 provides a summary of the variable measurements. We expect that larger firms, large profits, large financing needs and that issue standalone reports to be associated with high quality environmental disclosure. Table 2 summarizes the measurement of variables.

\section{Empirical results}

\subsection{Descriptive statistics}

Descriptive statistics of all variables used in the analysis are shown in Table 3. The Dependant variable is the quality of environmental disclosure in annual reports and stand-alone reports. QUAL presents a minimum of 0 and mean of $18.1 \%$ indicating that the efforts of French companies to improve the quality of environmental disclosure are still not have great importance as financial reporting. However, it seems that quality increases from one year to another increasing from $12.49 \%$ in 2009 to $22.77 \%$ in 2014(see Fig. 1), indicating that the introduction of new regulations, mainly the Grenelle Act of 2012 affects the attitudes of companies toward credibility

\footnotetext{
${ }^{2}$ ASSET4 environmental pillar measures a company's impact on living and non-living natural systems, including the air, land and water, as well as completes ecosystems. It reflects how well a company uses best management practices to avoid environmental risks and capitalize on environmental opportunities in order to generate long-term shareholder value. Further information can be found here http://extranet. datastream.com/data/ASSET4\%20ESG/Index.htm.
} 
Table 3 Summary statistics of dummy variables

\begin{tabular}{lcc}
\hline Variables & Frequency & Percent \\
\hline ENV COM & 96 & \\
0 & 474 & 16.84 \\
1 & & 83.16 \\
AUDIT & 157 & \\
0 & 411 & 27.64 \\
1 & & 72.36 \\
STAND REPT & 347 & \\
0 & 223 & 60.88 \\
1 & & 39.12 \\
\hline
\end{tabular}

ENVT $\mathrm{COM}=$ take a value of 1 if an environmental committee exists within the board and 0 otherwise. AUDIT $=1$ if an environmental audit is provided and 0 otherwise. STAND REPORT $=$ release of a stand-alone report: dummy variable equal to 1 if company releases a stand-alone CSR report, 0 otherwise

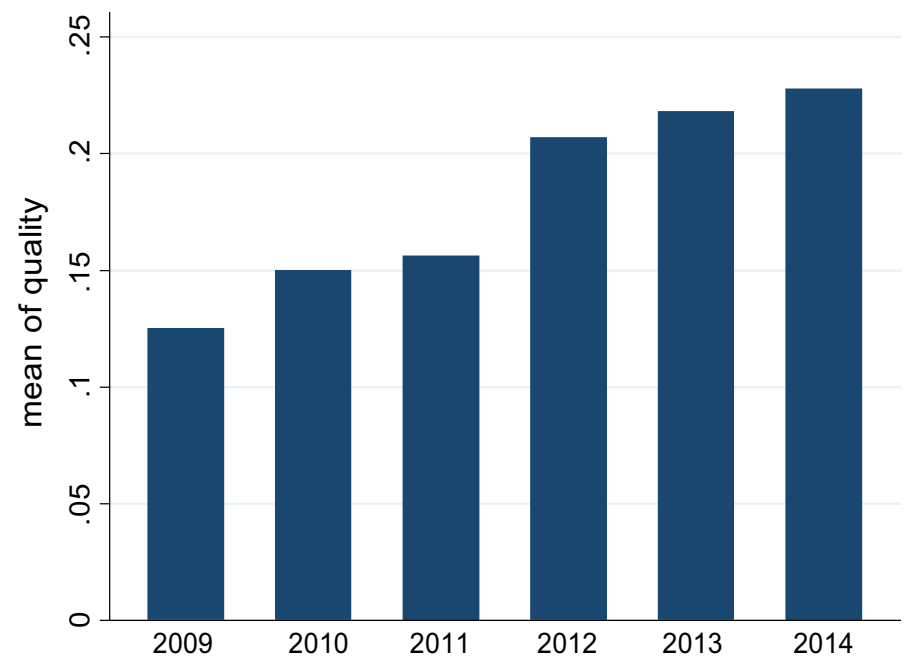

Fig. 1 Evolution of the mean of environmental disclosure quality over year

of such disclosure. These results are agree with the findings of Chauvey et al. (2014) in the French context who indicates that even if the regulatory framework of environmental reporting is being approached, it appears to be so without a considerable increase in informational quality.

The descriptive statistics of continuous independent variables indicates that gender diversity GEND DIV on the board, which represents the percentage of women on the board, ranges from 0 to 55 as a maximum with a mean of $21.68 \%$. This is higher than the $14.1 \%$ reported in Al Shaer and Zaman (2016). However, this result indicates that the presence of women in the boardroom is still moderate. During the same period, the percentage of independent board members presents 
Table 4 Summary descriptive statistics: continuous variables

\begin{tabular}{lcccccccc}
\hline Variables & $\mathrm{N}$ & Mean & SD & Min & Max & p25 & Median & p75 \\
\hline QUAL & 570 & 0.181 & 0.128 & 0 & 0.503 & 0.0667 & 0.181 & 0.272 \\
GEND DIV & 570 & 21.68 & 11.18 & 0 & 55 & 12.50 & 21.88 & 30 \\
INDEP & 570 & 49.30 & 19.70 & 0 & 100 & 33.32 & 45.45 & 62.70 \\
ENVT PERF & 570 & 80.15 & 19.34 & 10.84 & 94.86 & 74.63 & 89.17 & 92.94 \\
D_POLL & 570 & 5.411 & 1.072 & 2.204 & 8.205 & 4.886 & 5.390 & 6.070 \\
SIZE & 570 & 7.154 & 0.720 & 5.836 & 9.316 & 6.647 & 7.044 & 7.510 \\
PROF & 570 & 3.182 & 4.636 & -10.25 & 19.46 & 0.767 & 3.111 & 5.456 \\
LEV & 570 & 0.2518 & 0.1440 & 0.0118 & 0.5484 & 0.1527 & 0.2564 & 0.3489 \\
\hline
\end{tabular}

$\mathrm{ENVT} C \mathrm{COM}=$ take a value of 1 if an environmental committee exists within the board and 0 otherwise. AUDIT $=1$ if an environmental audit is provided and 0 otherwise. GEND DIV = Percentage of women in the board members at the end of the fiscal year. INDEP = Percentage of independent board members as reported by the company. ENVT PERF = ASSET4's Environmental Score. D-POLL= Natural Log of Total $\mathrm{CO}_{2}$ and $\mathrm{CO}_{2}$ equivalents emissions. SIZE =the natural $\log$ of total assets. PROF $=$ Net income/ total assets in \%. LEV $=$ Debt to Assets ratio. STAND REPORT=Release of a stand-alone report: dummy variable equal to 1 if company releases a stand-alone CSR report, 0 otherwise

a mean of $49.30 \%$ and maximum of $100 \%$. Our findings are lower than the $54.5 \%$ mean reported by Liao et al. (2014) and almost the same findings of Ducassy and Montandrau (2015) for the SBF 120 companies with a mean of 47\%. This indicates that French companies present on average highly independent boards.

In terms of environmental performance ENVT PERF, the mean environmental score as calculated by ASSET4 is 80.15. According to, the environmental score measures "how well a company uses best management practices to avoid environmental risks and capitalize on environmental opportunities to generate long term shareholder value". This result is similar to Del Bosco and Misani (2016) who reported a mean ASSET4 environmental score of 87.31 for companies in the Euronext Paris. The degree of pollution of the firm D_POLL presents a mean of 5.41 Tons of $\mathrm{CO}_{2}$ and $\mathrm{CO}_{2}$ equivalent emissions, thus implying that the level of emissions of French companies is considered high, creating a high degree of pollution.

Regarding the control variables, it can be observed that the sample companies are relatively large firms with a mean SIZE of 7.14 between a minimum of 5.83 and maximum of 9.31. This is similar to the result reported by Lakhal (2015) for the French listed companies with mean 7.87. In terms of profitability PROF, the mean of net income to total assets equals $3.182 \%$. For the leverage LEV which equals total debt to total assets, the mean 0.2518 is close to the mean of 0.20 reported by Chauvey et al. (2014) and 0.2734 reported by Lakhal (2015) for the SBF 1230 French companies.

Table 4 depicts descriptive statistics for the dummy variables, $83.16 \%$ of sample companies designated a specific environmental committee of the board, which implies that the majority of firms put in place environmental committees in order to review their sustainability policies and activities. For the environmental audit, $72.36 \%$ of companies provide third party verification for their information. This implies that the majority of firms' seek to comply with existing laws and 
Table 5 Correlation matrix $(\mathrm{N}=570)$

\begin{tabular}{|c|c|c|c|c|c|c|c|c|}
\hline & QUAL & $\begin{array}{l}\text { GEND } \\
\text { DIV }\end{array}$ & INDEP & ENVT PERF & D_POLL & SIZE & PROF & LEV \\
\hline QUAL & 1.000 & & & & & & & \\
\hline $\begin{array}{r}\text { GEND } \\
\text { DIV }\end{array}$ & $0.183^{* * *}$ & 1.000 & & & & & & \\
\hline INDEP & $-0.100 *$ & 0.074 & 1.000 & & & & & \\
\hline $\begin{array}{l}\text { ENVT } \\
\text { PERF }\end{array}$ & $0.290 * * *$ & $0.116^{* *}$ & 0.035 & 1.000 & & & & \\
\hline D_POLL & $0.147 * * *$ & 0.026 & $0.105^{*}$ & $0.335 * * *$ & 1.000 & & & \\
\hline SIZE & 0.190 *** & $0.188^{* * *} *$ & 0.016 & $0.449 * * *$ & $0.345^{* * *} *$ & 1.000 & & \\
\hline PROF & -0.082 & 0.034 & -0.044 & $-0.210^{* * *}$ & $-0.244 * * *$ & $-0.299 * * *$ & 1.000 & \\
\hline LEV & $0.185^{* * * *}$ & -0.030 & $-0.083 *$ & $-0.096^{*}$ & $0.129 * *$ & -0.023 & $-0.206^{* * *}$ & 1.000 \\
\hline
\end{tabular}

ENVT COM $=$ take a value of 1 if an environmental committee exists within the board and 0 otherwise. $\mathrm{AUDIT}=1$ if an environmental audit is provided and 0 otherwise. GEND DIV = percentage of women in the board members at the end of the fiscal year. INDEP=percentage of independent board members as reported by the company. ENVT PERF=ASSET4's Environmental Score. D-POLL=natural log of total $\mathrm{CO}_{2}$ and $\mathrm{CO}_{2}$ equivalents emissions. SIZE =the natural log of total assets. PROF $=$ Net income/total assets in \%. LEV = debt to assets ratio. STAND REPORT= release of a stand-alone report: dummy variable equal to 1 if company releases a stand-alone CSR report, 0 otherwise

regulation in term of assurance of non-financial information, particularly in relation to the Grenelle Act II. Finally, only 39.12\% of companies issue standalone reports other than annual reports. This indicates that the majorities are still not familiar with the voluntary disclosure of such reports and prefer to provide the required information in the annual reports, as required by regulation.

\subsection{Univariate analysis: correlation matrix}

Table 5 shows the bivariate relations resulting from the pairwise Pearson correlation matrix between the quality of environmental disclosure and the independent variables. Correlations are estimated using longitudinal and pooled data across the six-year sample period. As documented earlier, QUAL of environmental disclosure is positively and significantly associated at the 5\% level with GEND DIV, ENVT PERF, D_POLL, and SIZE and LEV. However, contrary to what is expected, INDEP is negatively and positively associated with quality of environmental disclosure. PROF had no significant correlation with QUAL. Significant correlation between SIZE and ENVT PERF exist at 0.44. However, according to Field (2009), this is not considered a problem as it falls below the maximum threshold of 0.8 . Therefore, the correlation matrix results do not raise any issues concerning multicollinearity. We checked for the multi-collinearity issue using the variance inflation factor (VIF). After running multiple regression analysis is Stata, we find that the maximum VIF is 1.30. As a rule of thumb, a variable with VIF greater than 10 need further investigation (Hail and Leuz 2006). Therefore, the model does not suffer from multicollinearity. 
Table 6 Determinants of environmental disclosure quality: fixed effects regression

\begin{tabular}{ll}
\hline Variables & Quality \\
\hline ENVT COM & $-0.0203(0.0148)$ \\
AUDIT & $0.0536^{* * *}(0.0136)$ \\
GEND DIV & $0.00104 * *(0.000524)$ \\
INDEP & $-0.000706^{* * *}(0.000249)$ \\
ENVT PERF & $0.00154 * *(0.000314)$ \\
D_POLL & $0.00376(0.00526)$ \\
SIZE & $0.00786(0.00834)$ \\
PROF & $0.000936(0.00116)$ \\
LEV & $0.00177 * *(0.000360)$ \\
STAND REP & $-0.0279 * * *(0.0107)$ \\
Constant & $-0.0671(0.0585)$ \\
Observations & 568 \\
R-squared & 0.209 \\
Adj R-squared & 0.193 \\
Industry FE & Yes \\
Year FE & Yes \\
\hline
\end{tabular}

ENVT $\mathrm{COM}=$ take a value of 1 if an environmental committee exists within the board and 0 otherwise. AUDIT $=1$ if an environmental audit is provided and 0 otherwise. GEND DIV = percentage of women in the board members at the end of the fiscal year. INDEP $=$ percentage of independent board members as reported by the company. ENVT PERF=ASSET4's Environmental Score. $\mathrm{D}-\mathrm{POLL}=$ natural $\log$ of total $\mathrm{CO}_{2}$ and $\mathrm{CO}_{2}$ equivalents emissions. $\mathrm{SIZE}=$ the natural $\log$ of total assets. $\mathrm{PROF}=$ net income/total assets in $\% . \mathrm{LEV}=$ debt to Assets ratio. STAND REPORT $=$ release of a stand-alone report: dummy variable equal to 1 if company releases a stand-alone CSR report, 0 otherwise

$*$, **, and ***significance at $p<0.01 ; p<0.05$ and $p<0.10$ respectively

\subsection{Empirical tests and findings}

Table 6 depicts the results of panel data fixed effects regression estimates or the cross sectional time series regression with observations from all 6 years. These results highlight the determinants of environmental disclosure quality. As indicated in the table, the models are highly significant (based on the model F-statistic) with an adjusted $\mathbf{R} 2$ of 0.189 .

Unlike what was predicted earlier, the association between the existence of an environmental committee ENV COM on the board and quality are not significant. Therefore, hypothesis $\mathrm{H} 1$ is not supported. A possible explanation for this result is that the presence of an environmental committee on the board for French companies does not only aim to set up better environmental disclosure policy for stakeholders. It may be viewed as a legitimacy tool and not necessarily to improve non-financial reporting policy. 
The third party verification of environmental information is a mandatory act for French listed companies from April 2012 with the new regulation Grenelle II. The result is consistent with neo-institutional theory more precisely the normative pressures exercised by French regulation in terms of assurance of non-financial information when companies must also seek independent third-party verification for their reports, as well as an opinion about the sincerity of information disclosed. AUDIT is positively and significantly associated with quality at a $1 \%$ level. Thus, hypothesis $\mathrm{H} 2$ is supported.

The results are largely in agreement with the existing French regulation in term of non-financial information assurance, which implies that French companies go beyond just the publication of such information and verify it. The results are in line with the findings of Moroney et al. (2012), which show a high quality of voluntary environmental disclosure scores for assured companies rather than non-assured firms. For the French context, Gilet (2011) conducted an interview with sustainability managers and found that companies used assurance to ensure accountability to stakeholders and the reliability of disclosed information. Recently, Braam et al. (2016) confirmed a positive and significant association at the 5\% level between external verification and the reliability and accuracy of environmental information provided in corporate environmental reports. Therefore, we conclude from the results below that third party assurance affects the credibility of disclosed information because, under French regulation, any incomplete or omitted information (indicators) without any explanation should be reported in auditors' statements. The opinion of the auditor concerns the accuracy of published information, the explication, if any, in the absence of required information and the procedures implemented to conduct the audit (KPMG 2014). In summary, it seems that French companies in their strategy and vision related to nonfinancial disclosure focus more on compliance with law and regulations (assurance) rather than legitimacy issues(role of the environmental committee).

It was expected that diversity of the board, which includes independence INDEP and gender diversity GEND DIV, would increase quality of the environmental disclosure. The findings are consistent with our expectations, thus hypothesis $\mathrm{H} 3$ is confirmed while $\mathrm{H} 4$ is rejected.

As evidenced in prior literature, the presence of women at the top level of management in the organization has been attracting considerable attention mainly in the issue of CSR. We find the presence of women on the board of directors not only allows companies to be better financial performers, ${ }^{3}$ but also take concerted action toward another pillar of sustainability, environmental performance. To the best of the author's knowledge, there is even less research on the relationship between gender diversity in an organization as a whole and that organization's environmental disclosure quality in the French context. The findings provide support for the resource dependence theory and human capital theory. It indicates that the proportion of female on the board GEND DIV allows firms to drawn from a variety of

\footnotetext{
3 Firms managed by females executives show higher level of financial performance than males because female are more risk-averse and less overconfident (Barber and Odean 2001).
} 
skills, education and experience to provide more accurate environmental disclosure. These theories focus on the role of individual's capabilities which are manifested in the stock of education, skills and experience in influencing the performance of the board of directors' members and thus environmental reporting quality. Thus, our findings are consistent with our prior expectations and H4 is supported. These results are in line with the findings of Liao et al. (2014) which find that a small number of females on the board of directors do make a difference in GHG disclosure decisions. On the other hand, Konrad and Kramer (2006) find that females tend to be more concerned about the demands of stakeholders which can explain our results. Post et al. (2011) argued that women might be more aware about of environmental issues and draw further attention to them in order to reduce the perceived risks.

Furthermore, we have shown that firms, which tend to be more gender conscious, tend to pay more attention to the quality of the disclosed information. On this level, Gul et al. (2011) indicate that females tend to adopt more trust building relationships compared to males and thus, may put more emphasis on providing high quality information. Recently, and in the same vein, Al Shaer and Zaman (2016), based on the idea that a diverse board will pay greater attention to stakeholders' concerns, they used a range of proxies for gender diversity to test its effect on the quality of sustainability reporting. They find that gender diverse boards are positively and significantly associated at a $1 \%$ level with a higher quality of sustainability reporting and independent female directors have a greater effect on sustainability reporting quality than male directors. Another possible explanation is that in France, the context of the current study, the law requires $50 \%$ gender parity on the board of every public firm by 2015, which reinforces the role of women on boards of directors in disclosure policy particularly. Moreover, there was the European Parliament to impose a female quota for non-executive directors of companies listed on stock exchanges throughout the European Union (COM 614, 2012). ${ }^{4}$

The presence of independent directors on the board is significantly but negatively associated with quality of environmental disclosure. In this sense, it is possible to affirm that these directors do not enhance non-financial disclosure. These results show an opposition of independent directors to environmental disclosure practices. These findings are in line with Garcia-Sanchez and Martinez Ferrero (2016) find a negative and significant association between the utility and comparability of CSR disclosure and board independence. In the Saudi Arabia context, Alotaibi and Hussainy (2016) find similar finding through a negative influence of board independence on the quality of CSR disclosure. Furthermore, Zhang et al. (2013) find the proportion of outside directors to be negatively and significantly associated with corporate social performance indicating that board independence is not adequate to enhance positive ratings of CSR. Moreover, our results are opposite to the findings of Ducassy and Montandrau (2015) who find a positive and significant relationship between

\footnotetext{
${ }^{4}$ COM 614. 2012. Proposal for a directive COM (2012) 614 final: Proposal for a directive of the European Parliament and of the Council on improving the gender balance among non-executive directors of companies listed on stock exchanges and related measures. Brussels: EuropeanCommission. http://eurle x.europa.eu/legalcontent/EN/TXT/PDF/?uri=CELEX:52012PC0614andfrom=EN.
} 
CSR performance and independence of the board. They explain that by the fact that members of the boards who have no personal vested interests improve firm's social performance. Therefore, it can be argued from the results obtained that the unwillingness of outside independent directors to draw further attention to non-financial disclosure may be because of the absence of clear insight about the credibility of such information. On this level, the misleading nature of disclosed information will increase the reputation risks of those outside independent directors.

According to stakeholder' theory, companies should be able to respond to complex regulations and build trusting, engaging, and constructive dialogue with their stakeholders in order to develop a competitive advantage. Environmental disclosure about the firm's performance will help stakeholders get a better sense of how companies can effectively contribute to a more just and sustainable world. On this level the association between environmental performance ENVT PER measured by the ASSET4' environmental score presents a positive and significant association at the $1 \%$ level with the quality of environmental disclosure. This association has been extensively reviewed in prior literature using a variety of proxies lead to mixed results. This result is consistent with our predictions and thus hypothesis H5 is confirmed. These results are in line with Al-Tuwaijiri et al. (2004) who argued that firms with good environmental performance use environmental disclosure as a tool to disseminate "good news" to stakeholders. Cho et al. (2010) find that a firm's environmental performance is positively associated with "optimism "level of environmental disclosure. These results could be explained by the fact that companies with poor environmental performance use more optimistic language tone in their disclosure. However, this association is negative and significant to environmental disclosure "certainty" indicating that firms with bad environmental performance use less certain language for disclosure. We explain our findings in that whether firms have good or bad ENVT PERF, they use environmental disclosure either to demonstrate confidence in their performance or to offer an explanation. To sum up, consistent with stakeholder' theory, firms with good ENVT PERF, manifested by the ability of their management to avoid environmental risks, produce more credible environmental information in order to reinforce the confidence of their stakeholders.

The degree of pollution D_POLL measured as the total of $\mathrm{CO}_{2}$ and $\mathrm{CO}_{2}$ equivalent emissions provides no significant association with the quality of environmental disclosure. This result could be explained by the existing regulatory framework of GHG emissions in France where listed companies are required to publish information about their emissions in another document called "Bilan Carbone" aside from the annual reports or stand-alone reports.

For the control variables, SIZE and profitability PROF have no association with quality of environmental disclosure. Leverage LEV presents a positive and significant association at the $1 \%$ level, indicating that companies with a high level of leverage tend to disseminate a high amount and better quality of nonfinancial information in order to reduce the negative impact of being highly levered in the eyes of their investors. The issuance of standalone reports STAND REP is negatively and significantly associated with QUAL. In the French context, this is considered a voluntary act under the discretion of the manager. (Michelon et al. 2015) find that the introduction of such practice indicates the effectiveness of the firm's commitment to 
CSR and thus contributes to enhancing environmental disclosure quality. They find a positive and significant association between the content of CSR disclosure and the issuance of standalone reports. Contrary to our expectations, the issuance of standalone reports negatively affects the level and richness of environmental disclosure. This result could be explained by the fact that in France the publication of reports other than the annual reports is still voluntary and is not subject to mandatory verification. However, referring to our analysis, the majority of French listed companies use standalone reports to publish mandatory information which, may mislead firm's various stakeholders. Overall, mandatory information in the annual reports will be more appreciated by users.

\subsection{Additional sensitivity and robustness checks}

\subsubsection{An alternative measure of environmental disclosure quality}

To draw stronger inferences between the quality of environmental disclosure and the independent variables, we present a set of sensitivity tests. First, we replicate our analysis using an alternative measure of environmental disclosure quality based on the adoption of GRI principles following (Latridis 2013) to assess the robustness of our findings. The measure is a dummy variable and thus, we use logit specification tests. When we use the dummy variable GRI adoption as an alternative measure of environmental disclosure, ${ }^{5}$ the existence of an environmental committee on the board ENVT COM becomes positive and significant with the quality of environmental. This could be explained by the fact that firm 's "environmental committee members prefer to follow the reporting principles provided by GRI in presenting environmental information to stakeholders. Environmental performance ENVT PERF remains significant at the 5\% level. The degree of pollution of the company becomes positive and significant at the $1 \%$ level which provides evidence that companies following the GRI reporting principles tend to provide the maximum of information even those which is mandatory in order to provide a complete picture about the firm's environmental commitments and impact on the natural environment.

\subsubsection{Controlling for industry sensitivity}

Prior research documents systematic differences in environmental disclosure quality across industries and suggests that the role of these disclosures may also vary by the environmental sensitivity of the industry. Thus, including firms from both sensitive and non-sensitive industries has the potential to enhance our understanding of environmental disclosures. We perform another sensitive analysis to verify whether the different tests in disclosure scores are robust to the classification of sample firms as operating in environmentally sensitive industries ${ }^{6}$ (basic materials,

\footnotetext{
5 DataStream ICB (Industry Classification Benchmark) industry classification.

6 Results, not tabulated, are generally consistent with those in Table 6.
} 
Table 7 Additional analysis: regressions of quality of environmental disclosure: industry subsamples

\begin{tabular}{lll}
\hline & Quality & \\
\cline { 2 - 3 } & Polluted firms & Non polluted firms \\
\hline ENVT COM & $-0.0127(0.0209)$ & $-0.0287(0.0207)$ \\
AUDIT & $0.0601 * * *(0.0191)$ & $0.0490 * *(0.0199)$ \\
GEND DIV & $0.00158 * *(0.000786)$ & $0.000709(0.000703)$ \\
INDEP & $-0.00115^{* * *}(0.000363)$ & $-0.000407(0.000343)$ \\
ENVT PER & $0.00114 * *(0.000433)$ & $0.00184 * * *(0.000446)$ \\
D_POLL & $0.0126(0.00785)$ & $-0.00248(0.00702)$ \\
SIZE & $-0.00288(0.0135)$ & $0.0144(0.0106)$ \\
PROF & $-0.000832(0.00173)$ & $0.00186(0.00155)$ \\
LEV & $0.000735(0.000545)$ & $0.00237 * *(0.000475)$ \\
STAND REP & $-0.0240(0.0161)$ & $-0.0298 * *(0.0143)$ \\
Constant & $0.0199(0.0960)$ & $-0.112(0.0756)$ \\
Observations & 208 & 360 \\
R-squared & 0.251 & 0.171 \\
Adj R ${ }^{2}$ & 0.213 & 0.147 \\
year FE & YES & YES \\
industry FE & YES & YES \\
\hline
\end{tabular}

ENVT $\mathrm{COM}=$ take a value of 1 if an environmental committee exists within the board and 0 otherwise. AUDIT $=1$ if an environmental audit is provided and 0 otherwise. GEND DIV $=$ percentage of women in the board members at the end of the fiscal year. INDEP $=$ percentage of independent board members as reported by the company. ENVT PERF=ASSET4's Environmental Score. $\mathrm{D}-\mathrm{POLL}=$ natural $\log$ of total $\mathrm{CO}_{2}$ and $\mathrm{CO}_{2}$ equivalents emissions. $\mathrm{SIZE}=$ the natural $\log$ of total assets. $\mathrm{PROF}=$ net income/total assets in $\% . \mathrm{LEV}=$ Debt to Assets ratio. STAND REPORT $=$ release of a stand-alone report: dummy variable equal to 1 if company releases a stand-alone CSR report, 0 otherwise

$*$, **, and ***significance at $p<0.01 ; p<0.05$ and $p<0.10$ respectively

utilities, consumer goods, health care and oil\& Gas) and non-polluted industries (consumers services, financials, industrials, telecommunication and technology) following (Dhaliwal et al. 2014). Results remain the same as provided in Table 6. However, gender diversity GEND DIV becomes not significant for non-polluting companies, positive, and significant for polluting companies, which implies that the role of women is stronger in polluting companies because they are more visible to society and stakeholders. As a result, the presence of females on board of directors influence the quality of environmental reporting provided by polluting companies in order to add some legitimacy to their activities and enhance their reputation in the eyes of different stakeholders. The same results were obtained for independent directors, which are significant and negative for quality for the firms operating in environmentally sensitive industries. This provides evidence that diversity on the board of directors in general contributes to enhancing the credibility of environmental reporting 
Table 8 Regression results with dummy variable GRENELLE II act

\begin{tabular}{ll}
\hline Variables & Quality \\
\hline ENVT PERF & $0.00169 * * *(0.000311)$ \\
INDEP & $-0.000650 * * *(0.000248)$ \\
GEND DIV & $0.000708(0.000519)$ \\
D_POLL & $0.00349(0.00521)$ \\
AUDIT & $0.0459 * * *(0.0138)$ \\
ENVT COM & $-0.0200(0.0147)$ \\
GRENELLE II & $0.0349 * * *(0.0123)$ \\
SIZE & $0.00676(0.00827)$ \\
PROF & $0.000993(0.00115)$ \\
LEV & $0.00178^{* * *}(0.000359)$ \\
STAND REP & $-0.0249 * *(0.0110)$ \\
Constant & $-0.0590(0.0585)$ \\
Observations & 568 \\
$R$-squared & 0.216 \\
Adj $R$-squared & 0.2007 \\
\hline
\end{tabular}

ENVT $\mathrm{COM}=$ take a value of 1 if an environmental committee exists within the board and 0 otherwise. AUDIT $=1$ if an environmental audit is provided and 0 otherwise. GEND DIV = percentage of women in the board members at the end of the fiscal year. INDEP $=$ percentage of independent board members as reported by the company. ENVT PERF=ASSET4's Environmental Score. D-POLL $=$ natural $\log$ of total $\mathrm{CO}_{2}$ and $\mathrm{CO}_{2}$ equivalents emissions. GRENELLE II: dummy variable equal to 1 if the period is after2012 and 0 for the period before 2012. SIZE =the natural $\log$ of total assets. $\mathrm{PROF}=$ net income/total assets in \%. LEV = debt to Assets ratio. STAND REPORT = release of a stand-alone report: dummy variable equal to 1 if company releases a stand-alone CSR report, 0 otherwise. GENDD_res = the residuals of gender diversity

$*$, **, and ***significance at $p<0.01 ; p<0.05$ and $p<0.10$ respectively

mainly for firms that face large pressure from society and stakeholders due to the nature of their activities. Environmental performance remains positive and significant for all the models. Table 7 provides the results for polluting and non-polluting firms.

\subsubsection{The effect of the introduction of Grenelle act II}

As a third sensitivity test, since we are working on the French context, it's important to study whether the change in existing regulations in term of non-financial reporting has an effect on environmental disclosure. To do that, we generate a dummy variable, which equal to one if the year is after 2012 the period after the adoption of Grenelle act II, which reinforce the level of mandatory information disclosed and call for more credibility, and 0 otherwise. We run our regression using the period before and after 2012 the year of change. Results presented in Table 8 remain almost 
the same and the coefficient of the dummy variable Grenelle II is positive and significant at $10 \%$ for quality model. These results indicate the role that plays this new law in promoting the credibility of disclosed environmental information given that it requires the third party verification of this information. Moreover, after the adoption of Grenelle act II, only the independent directors in the board becomes non-significant for quality model which implies that the role of those directors become low in term of reporting policy.

A possible explanation is that companies start to comply with mandatory requirement without any pressure after the promulgation of the Grenelle law II that constitutes an incentive for them to disclose mandatory indicators and pay more attention for the quality.

\subsubsection{Controlling for potential endogeneity problems}

Endogeneity occurs for several reasons including omitted variable biased, measurement error and simultaneity/reverse causation. Prior research has shown that board gender diversity is endogenous (Harjoto et al. 2015; Gul et al. 2013). Hence, similar to prior research we test for Endogeneity of gender diversity. A Durbin-Wu-Hausman test, which uses two-stage-least squares (2SLS) model, is used. Instrumental variables need to be included when testing Endogeneity. However, it is very difficult to find suitable instrumental variables that satisfy all the characteristics, which is why many studies have mistakenly introduced weak instrumental variables (Larcker and Rusticus 2010). Following Davidson and Mackinnon (1993), we used the residuals of endogenous variables (gender diversity) as a suitable instrumental variable. The residuals are included in the main models as the instrumental variables to test for Endogeneity. The results and process to test for Endogeneity are shown in Table 9. In the first equation, we examine factors affecting gender diversity using the variables used by Harjoto et al. (2015). Following this study independent variables in our first stage regression are total assets, market performance (Tobin's Q), non-executives' directors, accounting performance (ROA), women employee, Lag gender diversity (percentage of female in the board), sales growth and return.

The error (residual) term GENDD_res is predicted and induced into the second regression. The test shows in Table 10 that the residuals of gender diversity is insignificant Prob $>F=0.1909$. Thus, the test indicates that there is no Endogeneity issue in the model.

\section{Concluding remarks, limitations and future research}

This paper theoretically examines the logically plausible association between environmental disclosure quality and various factors related to the strategy and vision of firms, diversity of the board and factors related to the environment. Using content analysis of annual and standalone reports of French listed companies in the SBF 120 from 2009 to 2014, we self-construct our index for quality of environmental disclosure. We draw upon qualitative attributes of financial reporting derived from recommendations of the IASB, FASB and GRI guidelines following Chauvey et al. (2014) 
Table 9 Using Durbin-WuHausman (DWH) test for endogeneity: regression of gender diversity

\begin{tabular}{ll}
\hline Variables & GEND DIV \\
\hline ASSET & $0.977 * *(0.434)$ \\
TOBINQ & $-1.337 * *(0.592)$ \\
\%NON EXCUC & $0.0206(0.0230)$ \\
ROA & $0.000477(0.0649)$ \\
Women employee & $-0.00115(0.0167)$ \\
LAG GEND DIV & $0.748^{* * *}(0.0391)$ \\
SALES GRWTH & $-0.0204(0.0375)$ \\
RETURN & $-1.50 \mathrm{e}-05(1.73 \mathrm{e}-05)$ \\
Constant & $1.360(3.339)$ \\
Observations & 467 \\
R-squared & 0.655 \\
Adj R-squared & 0.623 \\
\hline
\end{tabular}

ASSET $=$ natural $\log$ of total assets. TOBINQ $=$ Tobin's $Q$ ratio calculated as the book value of assets minus the book value of equities plus the market value of equities, divided by the book value of assets. \%NON EXCUC = percentage of non-executives' directors. $\mathrm{ROA}=$ return on assets: net income/total assets in \%. Women employee $=$ percentage of women employee in the company. LAG GEND DIV=lagged value of percentage of female in the board. SALES GRWTH=net sales growth within 1 year. RETRUN $=$ Annual stock return during the year

$*$, **, and ***significance at $p<0.01 ; p<0.05$ and $p<0.10$ respectively

to develop a measure of environmental disclosure quality. We find that French companies provide low quality of disclosure however our obtained quality score remains better than the quality score of 10.69 obtained by Chauvey et al. (2014). We also document that quality score increased over the period from 2009 to 2014, which implies that French companies seek to provide credible information. Drawing upon a multi theory framework, the findings of panel data fixed effects regression are generally consistent with our expectations. We find that third party verification of environmental information plays a significant role in improving quality of environmental information. Neo institutional theory explains this finding, as firms tend to comply with normative pressures exercised by regulators in order to ensure transparency and credibility of disclosed information and reinforce the confidence of powerful stakeholders. In addition, our analyses show that diversity of the board manifested by its independence and the presence of female members provides contrasting influence on the quality of environmental information. Consistent with the view that boards that are more diverse are more effective, we find that the presence of female members on the board has positive and significant influence. However, independent directors have no association with quality which implies that those directors may not know the firm's environmental issues in depth and aim to protect their own interests. Further, firm's environmental performance has a positive and significant effect, which implies that environmental disclosure helps stakeholders get a better sense of how companies can effectively act as good performers. Additional tests have 
Table 10 Regression environmental disclosure quality and residuals of Gender diversity

\begin{tabular}{ll}
\hline Variables & Quality \\
\hline ENVT COM & $-0.0152(0.0308)$ \\
ENVT AUDIT & $0.0973^{* * *}(0.0280)$ \\
GEND DIV & $0.00220^{*}(0.00130)$ \\
INDEP & $-0.00101^{* *}(0.000508)$ \\
ENVT PERF & $0.00313^{* * *}(0.000640)$ \\
D-POLL & $-0.000227(0.0105)$ \\
SIZE & $0.00680(0.0165)$ \\
PROF & $0.00345(0.00235)$ \\
LEV & $0.00386^{* * *}(0.000724)$ \\
STAND REP & $-0.0614^{* * *}(0.0214)$ \\
GENDD_res & $-0.00269(0.00205)$ \\
Constant & $-0.0738(0.116)$ \\
Observations & 468 \\
R-squared & 0.201 \\
Adj R-squared & 0.181 \\
\hline
\end{tabular}

ENVT $\mathrm{COM}=$ take a value of 1 if an environmental committee exists within the board and 0 otherwise. AUDIT $=1$ if an environmental audit is provided and 0 otherwise. GEND DIV = percentage of women in the board members at the end of the fiscal year. INDEP $=$ percentage of independent board members as reported by the company. ENVT PERF=ASSET4's Environmental Score. $\mathrm{D}-\mathrm{POLL}=$ natural $\log$ of total $\mathrm{CO}_{2}$ and $\mathrm{CO}_{2}$ equivalents emissions. $\mathrm{SIZE}=$ the natural $\log$ of total assets. $\mathrm{PROF}=$ net income/total assets in $\% . \mathrm{LEV}=$ debt to assets ratio. STAND REPORT $=$ release of a stand-alone report: dummy variable equal to 1 if company releases a stand-alone CSR report, 0 otherwise. GENDD_res $=$ the residuals of gender diversity

$*$, **, and ***significance at $p<0.01 ; p<0.05$ and $p<0.10$ respectively

been applied to check the robustness of our results. Sensitivity tests using alternative measures of quality (GRI adoption) provide generally consistent results with our main findings. Moreover, we check the Endogeneity issue following prior research and find no problem.

We recognize that our study has some limitations. The findings are restricted to large companies and do not take into consideration other significant companies which are concerned with the application of the existing regulations. In addition, we acknowledge that our measure of environmental disclosure quality may be criticized for subjectivity. It may not capture all dimensions of quality. Nevertheless, we believe that our constructed index is a good attempt to refute the assumption that quantity is a good proxy of quality and to go beyond the traditional measures. Finally, our study has important implications for theory, standards setters and policy makers. First, this research focuses on the unexplored area of literature related to the quality of non-financial reporting drawing upon the regulatory framework of financial reporting. Second, it sheds light on whether various factors related to the 
diversity of the board, environmental performance and factors related to the environment could affect the credibility of disclosed information using a multi theory framework. The findings of this research could be seen as another important implication for standards setters and policy makers as it recommends thinking about implementing a generally accepted framework of non-financial reporting to answer the demand for more transparency and accountability.

Future research should pursue closer consideration of the effect of other governance variables using other theoretical frameworks. In addition, future studies could study the effect of the structure of environmental committee within the boards. We also suggest studying other diversity issues in the boards such as ethnicity, age, experience, and tenure. We also suggest studying whether there is an effect of IFRS adoption on environmental disclosure.

Open Access This article is distributed under the terms of the Creative Commons Attribution 4.0 International License (http://creativecommons.org/licenses/by/4.0/), which permits unrestricted use, distribution, and reproduction in any medium, provided you give appropriate credit to the original author(s) and the source, provide a link to the Creative Commons license, and indicate if changes were made.

\section{Appendix 1: Environmental disclosure index}

General environmental policy.

- Company efforts to take into account environmental issues and,

- Where appropriate, assessments or environmental certifications.

- Employee training programs on environmental protection.

- Budget dedicated to environmental protection and environmental risk mitigation.

- Financial provisions for environmental risk and pollution.

- Rand D expenditures for pollution abatement.

- Financing for pollution control equipment or facilities.

- The implementation of HSE (Health Safety Environment) approach.

Pollution and waste management.

- Measures to prevent, reduce, or compensate for air,

- Measures to prevent, reduce, or compensate for water,

- Measures to prevent, reduce, or compensate for soil emissions severely affecting the environment.

- Measures to prevent, recycle, and dispose of waste.

- Taking into account noise and other forms of pollution specific to activity.

- Significant environmental impacts of transporting products and other goods and materials used for the organization's operations, and transporting members of the workforce.

Sustainable use of resources. 
- Water use and water supply based on local constraints.

- Percentage and total volume of water recycled and reused.

- The consumption of raw materials and steps taken to improve their efficient use.

- Energy consumption,

- Measures to improve energy efficiency.

- Percentage of renewable energy used.

- Land use.

Climate change.

- Greenhouse gas emissions.

- Adaptation to climate change impacts.

- Initiatives to reduce greenhouse gas emissions and reductions achieved.

- $\mathrm{NO}_{\mathrm{x}}, \mathrm{SO}_{\mathrm{x}}$, and other significant air emissions by type and weight.

- Total number and volume of significant spills.

Protection of biodiversity.

- Measures taken to preserve or enhance biodiversity.

Environmental management.

- Presence of Independent verification/assurance about environmental information disclosed.

- Joint projects with other firms on environmental management.

- Goals and targets.

- Certification ISO 14000.

- Participation in elaborating of environmental standards.

- The existence of environmental department or office for pollution control.

- Existence of terms and conditions applicable to suppliers and/or customers regarding environmental practices.

- A statement about the firm's compliance with existed environmental regulation or other schemes (GRI, UNGC, ISO26000).

- Environmental litigation/lawsuits against the company.

- External environmental awards, prizes/or inclusion in sustainability index.

- Commitments to an environmental or sustainable development charter.

- Extra financial environmental rating by Sustainability Rating Agency.

- Participation in environmental association/initiatives to improve environmental practices. 


\section{Appendix 2: Environmental disclosure quality measurement}

\begin{tabular}{|c|c|c|c|}
\hline $\begin{array}{l}\text { Qualitative character- } \\
\text { istics }\end{array}$ & Measurement & Authors & Indexes \\
\hline Relevance & $\begin{array}{l}\text { Time specification } \\
\text { 1: Forward looking } \\
\text { information } \\
\text { 1: Backward informa- } \\
\text { tion (present or past) } \\
0 \text { : No time specifica- } \\
\text { tion }\end{array}$ & $\begin{array}{l}\text { Michelon et al. (2015) } \\
\text { Beretta and Bozzolan } \\
\text { (2008) }\end{array}$ & $R E L V_{i}=\frac{\sum_{i=1}^{n} \text { Relevance }_{i}}{\text { MAX Relevance }}$ \\
\hline Neutrality & $\begin{array}{l}\text { 1: Positive information } \\
\text { 1: Negative informa- } \\
\text { tion } \\
0 \text { : Neutral information }\end{array}$ & $\begin{array}{l}\text { GRI (2006) } \\
\text { Chauvey et al. (2014) } \\
\text { Guthrie and Parker (1990) }\end{array}$ & $N E U T R_{i}=\frac{\sum_{i=1}^{n} \text { Neutrality }_{i}}{\text { MAX Neutrality }}$ \\
\hline Clarity & $\begin{array}{l}\text { 1: Monetary } \\
\text { 1: Quantitative } \\
0: \text { Declarative (general) }\end{array}$ & $\begin{array}{l}\text { Cormier et al. (2005) } \\
\text { Michelon et al. (2015) } \\
\text { Botosan (1997) }\end{array}$ & $C L A R_{i}=\frac{\sum_{i=1}^{n} \text { Clarity }_{i}}{\text { MAX Clarity }}$ \\
\hline Comparability & $\begin{array}{l}\text { 1: Comparison with } \\
\text { previous period } \\
\text { 1: Comparison with } \\
\text { other organizations } \\
\text { 0: No comparison }\end{array}$ & Jonas and Blanchet (2000) & COMP $_{i}=\frac{\sum_{i=1}^{n} \text { Comparability }_{i}}{\text { MAX Comparability }}$ \\
\hline Verifiability & $\begin{array}{l}\text { 1: Presence of audit } \\
\text { of environment } \\
\text { disclosure } \\
\text { 0: No audit }\end{array}$ & $\begin{array}{l}\text { Grenelle Act II of } 2012 \\
\text { Simnett et al. (2009) }\end{array}$ & $V E R F_{i}=\frac{\sum_{i=1}^{n} \text { Verifiability }_{i}}{\text { MAX Verifiability }}$ \\
\hline
\end{tabular}

\section{References}

Adams, R., \& Ferreira, D. (2009). Women in the boardroom and their impact on governance and performance. Journal of Financial Economics, 94(2), 291-309.

Adams, R., de Haan, J., Terjesen, S., \& van Ees, H. (2015). Board diversity: Moving the field forward. Corporate Governance, 23(2), 77-82.

Al Shaer, H., \& Zaman, M. (2016). Board gender diversity and sustainability reporting quality. Journal of Contemporary Accounting and Economics. https://doi.org/10.1016/j.jcae.2016.09.001.

Alotaibi, K. O., \& Hussainy, K. (2016). Determinants of CSR disclosure quantity and quality: Evidence from non financial listed firms in Saudi Arabia. International Journal of Disclosure and Governance. https://doi.org/10.1057/jdg.2016.2.

Al-Tuwaijiri, S. A., Christensen, T. E., \& Hughes, K. E. (2004). The relations among environmental disclosure, environmental performance, and economic performance: A simultaneous equations approach. Accounting, Organizations and Society, 29, 447-471. 
Amran, A., Ping Lee, S., \& Selaraj, S. (2013). The influence of governance structure and strategic CSR toward sustainability reporting quality. Business Strategy and the Environment. https://doi. org/10.1002/bse. 1767 .

Ane, P. (2012). An assessement of the quality of environmental information disclosure of corporation in China. Systems Engineers Procedia, 5(2012), 420-426.

Barber, B. M., \& Odean, T. (2001). Boys will be boys: Gender, overconfidence, and common stock investment. Quarterly Journal of Economics, 116(1), 261-292.

Barros, C. P., Boubaker, S., \& Hamrouni, A. (2013). Corporate governance and voluntary disclosure in france (2013). The Journal of Applied Business Research, 29(2), 561-578.

Bear, S., Rahman, N., \& Post, C. (2010). The impact of board diversity and gender composition on corporate social responsibility and firm reputation. Journal of Business Ethics, 97(2), 207-221.

Beattie, V., McInnes, B., \& Fernley, S. (2004). A methodology for analysing and evaluating narratives in annual reports: A comprehensive descriptive profile and metrics for disclosure quality attributes. Accounting Forum, 28(3), 205-236.

Becker, G. (1964). Human capital: A theoretical and empirical analysis, with special reference to education. Chicago: University of Chicago Press. http://press.uchicago.edu/ucp/books/book/chicago/H/ bo3684031.html.

Beest, F., Braam, G., \& Boelens, S. (2009). Quality of financial reporting: Measuring qualitative characteristics. Working paper, Radboud University Nijmegen. http://www.dphu.org/uploads/attachemen ts/books/books_3437_0.pdf.

Ben Amar, W., Chang, M., \& Mcllkemy, P. (2015). Board gender diversity and corporate response to sustainability initiatives: Evidence from Carbon Disclosure Project. Journal of Business Ethics, 112(3), 463-497.

Beretta, S., \& Bozzolan, S. (2008). Quantity vs. quality: The case of forward looking disclosure. Journal of Accounting, Auditing and Finance, 3, 333-375.

Botosan, C. (1997). Disclosure level and the cost of equity capital. The Accounting Review, 72, 323-349.

Botosan, C. (2004). Discussion of a framework for the analysis of firm risk communication. The International Journal of Accounting, 39(3), 289-295.

Braam, G., Uit de Weerd, L., Harck, M., \& Huijbregts, M. (2016). Determinants of corporate environmental reporting: The importance of environmental performance and assurance. Journal of Cleaner Production, 129, 724-734.

Brammer, S., \& Pavelin, S. (2008). Factors influencing the quality of corporate environmental disclosure. Business Strategy and the Environment, 17(2), 120-136.

Brikey, R., Michelon, G., \& Patten, D. (2016). Does assurance on CSR reporting enhance environmental reputation? An examination in the US context. Accounting Forum, 40, 143-152.

Carter, D., D’Souza, F., Simkins, B., \& Simpson, W. (2010). The gender and ethnic diversity of US boards and board committees and firm financial performance. Corporate Governance, 18(5), 396-414.

Chauvey, J. N., Giordano-Spring, S., Cho, C., \& Patten, D. M. (2014). The normativety and legitimacy of the CSR disclosure: Evidence from France. Journal of Business Ethics, 130(4), 789-803.

Chelli, M., Durocher, S., \& Richard, J. (2014). France's new economic regulations: Insights from institutional legitimacy theory. Accounting, Auditing and Accountability Journal, 27(1ss2), 283-316.

Cho, C. H., Roberts, R. W., \& Patten, D. M. (2010). The language of US corporate environmental disclosure. Accounting, Organizations and Society, 35, 431-443.

Clarkson, P. M., Li, Y., Richardson, G. D., \& Vasvari, F. P. (2008). Revisiting the relation between environmental performance and environmental disclosure: An empirical analysis. Accounting, Organizations and Society, 33, 303-327.

Cooke, T. E. (1989). Disclosure in the corporate annual reports of Swedish companies. Accounting and Business Research, 19(74), 113-124.

Cormier, D., Magnan, M., \& Van Velthoven, B. (2005). Environmental disclosure quality in large German companies: Economic incentives, public pressures institutional conditions. European Accounting Review, 14(1), 3-39.

Davidson, R., \& MacKinnon, J. G. (1993). Estimation and inference in econometrics. New York: Oxford University Press.

De Villiers, C., \& Van Staden, C. J. (2011). Where firms choose to disclose voluntary environmental information. Journal of Accounting and Public Policy, 30, 504-525.

Del Bosco, B., \& Misani, N. (2016). The effect of cross listing on the environmental, social and governance performance of firms. Journal of World Business, 51, 977-990. 
Dhaliwal, D. S., Li, O. Z., Tsang, A., \& Yang, Y. G. (2014). Corporate social responsibility disclosure and the cost of equity capital: The roles of stakeholder orientation and financial transparency. Journal of Accounting and Public Policy, 33, 328-355.

DiMaggio, P. J., \& Powell, W. W. (1983). The iron cage revisited: Institutional isomorphism and collective rationality in organizational fields. American Sociological Review, 48, 147-160.

Ducassy, I., \& Montandrau, S. (2015). Corporate social performance, ownership structure, and corporate governance in France. Research in International Business and Finance, 34, 383-396.

El Ghoul, S. E., Geudhami, O., Kwok, C. Y., \& Mishra, D. R. (2011). Does corporate social responsibility affect the cost of capital? Journal of Banking and Finance, 35(9), 2388-2406.

Fédération des Experts Comptables Européens (FEE). (1999). FEE discussion paper towards a generally accepted framework for environmental reporting. A Discussion Paper issued for comment by the Environmental Task Force of the European Federation of Accountants (FEE), January. FEE.

Field, A. (2009). Discovering statistics using SPSS (3rd ed.). London: Sage publishers.

Forte, A. (2004). Antecedents of managers' moral reasoning. Journal of Business Ethics, 51(4), 315-347.

Fuente, J. A., Garcia-Sanchez, I. M., \& Lozano, M. B. (2017). The role of board of directors in the adoption of GRI guidelines for the disclosure of CSR information. Journal of Cleaner Production, 141, 737-750.

Garcia-Sanchez, I. M., \& Martinez Ferrero, J. (2016). Independent directors and CSR disclosure: The moderating effects of proprietary costs. Corporate Social Responsibility and Environmental Management. https://doi.org/10.1002/csr.1389.

Gilet, C. (2011). Study of sustainability verification practices: The French case. Journal of Accounting and Organizational Change, 8(1), 62-84.

Gray, J. V., \& Handley, S. M. (2015). Managing contract manufacturer quality in the presence of performance ambiguity. Journal of Operations Management, 38, 41-55.

GRI (Global Reporting Initiative). (2006). G3 sustainability reporting guidelines. Amsterdam: GRI.

GRI. (2013). Sustainability reporting guidelines. Boston: GRI [Global Reporting Initiative].

Gul, F. A., Hutchinson, M., \& Lai, K. M. (2013). Gender-diverse boards and properties of analyst earnings forecasts. Accounting Horizon, 27(3), 511-538.

Gul, F. A., Srinidhi, B., \& Ng, A. C. (2011). Does board gender diversity improve the informativeness of stock prices? Journal of Accounting and Economics, 51, 314-338.

Guthrie, J., \& Parker, L. (1990). Corporate social disclosure practice: A comparative international analysis. Advances in Public Interest Accounting, 3, 159-175.

Hail, L., \& Leuz, C. (2006). International differences in cost of equity capital: Do legal institutions and securities regulations matter? Journal of Accounting Research, 44, 485-531.

Hafsi, T., \& Turgut, G. (2013). Boardroom diversity and its effect on social performance: Conceptualization and empirical evidence. Journal of Business Ethics, 112(3), 463-479.

Harjoto, M., Laksmana, I., \& Lee, R. (2015). Board diversity and corporate social responsibility. Journal of Business Ethics, 132(4), 641-660.

Hillman, A. J., \& Dalziel, T. (2003). Boards of directors and firm performance: Integrating agency and resource dependence perspectives. Academic Management Review, 28(3), 383-396.

Hoechle, D. (2007). Robust standard errors for panel regressions with cross-sectional dependence. Stata Journal, 7(3), 281-312.

Hofstede, G., Hofstede, G. J., \& Minkov, M. (2010). Cultures and organisations: Software of the mind: Intercultural operation and its importance for survival. New York, NY: McGraw-Hill.

Ibrahim, N. A., \& Angelidis, J. P. (1995). The corporate social responsiveness orientation of board members: Are there differences between inside and outside directors? Journal of Business Ethics, 14, 405-410.

Jonas, G., \& Blanchet, J. (2000). Assessing quality of financial reporting. Accounting Horizons, 14(3), 353-363.

Kassinis, G., Panayiotou, A., Dimon, A., \& Katsifaraki, G. (2016). Gender and environmental sustainability: A longitudinal analysis. Corporate Social Responsibility and Environmental Management. https://doi.org/10.1002/csr.1386.

Kolk, A. (2008). Sustainability, accountability and corporate governance: Exploring multinationals' reporting practices. Business Strategy and the Environment, 17, 1-15. https://doi.org/10.1002/ bse. 511 .

Konrad, A., \& Kramer, V. W. (2006). How many women do boards need? Harvard Business Review, 84(12), 22. 
KPMG. (2014). Stratégie et communication RSE: tendances actuelles et futures. Changement climatiques et développement durable. Petite déjeuner conférence.

Lakhal, N. (2015). Corporate disclosure, ownership structure and earnings management: The case of French-listed firms. Journal of Applied Business Research, 31, 1493-1504.

Larcker, D. F., \& Rusticus, T. O. (2010). On the use of instrumental variables in accounting research. Journal of Accounting and Economics, 49(2), 186-205.

Latridis, G. E. (2013). Environmental disclosure quality: Evidence on environmental performance, corporate governance and value relevance. Emerging Markets Review, 14, 55-75.

Liao, L., Luo, L., \& Tang, Q. (2014). Gender diversity, board independence, environmental committee and greenhouse gas disclosure. British Accounting Review, 47(4), 409-424.

Matsumura, E. M., Prakash, R., \& Vera-Munoz, S. C. (2014). Firm value effects of carbon emissions and carbon disclosures. The Accounting Review, 89(2), 695-724.

Michael, J., \& Jill, F. (2009). Social and environmental report assurance: Some interview evidence. Accounting Forum, 34, 20-31.

Michelon, G., Pilonati, S., \& Ricceri, F. (2015). CSR reporting practices and the quality of disclosure: An empirical analysis. Critical Perspectives on Accounting, 33(1), 59-78.

Milne, M. J., \& Adler, R. W. (1999). Exploring the reliability of social and environmental disclosures content analysis. Accounting, Auditing and Accountability Journal, 12(2), 237-256.

Monjarret, C. G. (2014). L'étude de la pratique de vérification sociétale dans le contexte français de la loi Grenelle 2. Revue de l'organisation responsable, 9, 25-38.

Moroney, R., Windsor, C., \& Aw, Y. T. (2012). Evidence of assurance enhancing the quality of voluntary environmental disclosures: An empirical analysis. Accounting and Finance, 52, 903-939.

Peters, G. F., \& Romi, A. M. (2012). The effect of corporate governance on voluntary risk disclosures: Evidence from greenhouse gas emission reporting. Working Paper. University of Arkansas, Indiana University.

Petersen, M. (2009). Estimating standard errors in finance panel data sets: Comparing approaches. Review of Financial Studies, 22, 435-480.

Pfeffer, J., \& Salancik, G. (1978). The external control of organizations: A resource dependence perspective. New York, NY: Harper and Row.

Post, C., Rahman, N., \& McQuillen, C. (2015). From board composition to corporate environmental performance through sustainability-themed alliances. Journal of Business Ethics, 130, 423-435.

Post, C., Rahman, N., \& Rubow, E. (2011). Green governance: 'Boards of directors' composition and environmental corporate social responsibility. Business and Society, 50(1), 189-223.

Prado-Lorenzo, J.-M., \& Garcia Sanchez, I.-M. (2010). The role of the board of directors in disseminating relevant information on greenhouse gases. Journal of Business Ethics, 97, 391-424.

Rao, K., \& Tilt, C. (2015). Board composition and corporate social responsibility: The role of diversity, gender, strategy and decision making. Journal of Business Ethics. https://doi.org/10.1007/s1055 1-015-2613-5.

Rupley, K. H., Brown, D., \& Marshall, R. S. (2012). Governance, media and the quality of environmental disclosure. Journal of Accounting and Public Policy, 31(6), 610-640.

Seto-Pamies, D. (2013). The relationship between women directors and corporate social responsibility. Corporate Social Responsibility and Environmental Management, 22, 334-345.

Simnett, R., Vanstraelen, A., \& Chua, W. F. (2009). Assurance on sustainability reports: An international comparison. Accounting Review, 84(3), 937-967.

Solomon, A. (2000). Could corporate environmental reporting shadow financial reporting? Accounting Forum, 24(1), 30-55.

Spence, C., \& Gray, R. (2007). Social and environnemental reporting and the business case. ACCA research report No. 98. London: Certified Accountants Educational Trust.

Stern, N. (2006). The Stern review on the economics of climate change. Cambridge: Cambridge University Press.

Tagesson, T., Blank, V., Broberg, P., \& Collin, S.-O. (2009). What explains the extent and content of social and environmental disclosure on corporate web sites: A study of social and environmental reporting in Swedish listed corporations. Corporate Social Responsibility and Environmental Management, 16(6), 352-364.

Terjesen, S., Sealy, R., \& Singh, V. (2009). Women directors on corporate boards: A review and research agenda. Corporate Governance, 17(3), 320-337.

Zahra, S., \& Stanton, W. (1988). The Implications of Board of Directors' Composition for Corporate Strategy and Performance. International Journal of Management, 5, 261-272. 
Zhang, J. Q., Zhu, H., \& Ding, H. B. (2013). Board composition and corporate social responsibility: An empirical investigation in the post Sarbanes-Oxley Era. Journal of Business Ethics, 114, 381-392.

Publisher's Note Springer Nature remains neutral with regard to jurisdictional claims in published maps and institutional affiliations.

Fatma Baalouch, Ph.D. student in Accounting in the Institute of Higher Business Studies of Carthage, University of Carthage, Tunisia. She is affiliated to the LIGUE (University of Manouba, Tunisia). Previously, she gained professional experience in teaching accounting, as a contractual assistant, in the Institute of Management of Gabes and the Institute of Higher Business Studies of Carthage.

Salma Damak Ayadi, is Professor at IHEC Carthage (University of Carthage) in Tunisia. She teaches financial accounting theory and accounting standards. She completed her Ph.D. at the CREFIGE, Paris Dauphine University in France. Her research areas include social and environmental accounting, international accounting standards, and audit. Her research papers have been published in several international journals. She is affiliated to the LIGUE (University of Manouba, Tunisia).

Khaled Hussainey, is Professor of Accounting and Financial Management in Portsmouth Business School. He completed his Ph.D. in Accounting and Finance at the University of Manchester in 2004, and since then he has held academic positions at Plymouth University; Stirling University, Manchester University, and Ain Shams University, before joining the University of Portsmouth as a Professor of Accounting and Financial Management in August 2016. He has published more than 100 refereed papers in academic journals and international conferences proceedings. he has been awarded the prestigious 2007 Best Paper Award of the British Accounting Review for his paper "Loss firms' annual report narratives and share price anticipation of earnings" \& the prestigious 2012 Best Paper Award of the Journal of Risk Finance for my paper "Revisiting the capital structure puzzle: UK evidence". He is currently a Co-Editorin-Chief of Journal of Financial Reporting and Accounting; an Associate Editor for Journal of Applied Accounting Research and International Journal of Accounting, Auditing and Performance Evaluation.

\section{Affiliations}

\section{Fatma Baalouch ${ }^{1} \cdot$ Salma Damak Ayadi ${ }^{1} \cdot$ Khaled Hussainey $^{2}$}

Fatma Baalouch

fatmabaalouch2015@gmail.com

Salma Damak Ayadi

salmadamak@yahoo.fr

1 Institute of Higher Business Studies of Carthage, University of Carthage, Carthage, Tunisia

2 Faculty of Business and Law, Portsmouth Business School, University of Portsmouth,

Portsmouth, UK 